\section{THE SHI'ITE MUSLIMS IN THAILAND FROM AYUTTHAYA PERIOD TO THE PRESENT}

\author{
Julispong Chularatana ${ }^{1}$
}

\begin{abstract}
This article aims at studying and analyzing the status and development of the Shi'ite Muslim minority in Thailand from the $16^{\text {th }}$ century to the present day. The Shi'ite Muslims in Thailand developed and are informally separated into two groups. The original ones call themselves Chao Sen, which means Imam Hussein's followers, and are descended from IndoIranian Shi'ite Muslim ancestors who came from Iran and the Shi'ite States of India during the early $16^{\text {th }}$ century. The others, who are called by the original group Chi A Mai, which means new Shi'ites, converted from other beliefs to Shi'ism under the influence of the Shi'a revival after the Islamic Revolution in Iran in 1979.
\end{abstract}

\section{Introduction}

Shī'a Islam, also Shi'ite Islam or Shi'ism is the second largest denomination based on the Islamic faith after Sunni Islam. Shi'as adhere to the teachings of the Prophet Muhammad and the religious guidance of his family or his descendants known as Shi'a Imams. The Prophet Muhammad's bloodline continues only through his beloved daughter Fatima Zahra and his cousin Ali ibn Abi Talib,

\footnotetext{
${ }^{1}$ Lecturer, Department of History, Faculty of Arts, Chulalongkorn University
}

who alongside Muhammad's grandsons are their descendants. Shi'ites believe that Ali, rather than Abu Bakr, should have succeeded the Prophet Muhammad as khalifa (Netton 1922: 231). Thus, Shi'as consider imams, the Prophet Muhammad's descendants, as the true source of guidance while considering the first three ruling Sunni caliphs a historic occurrence and not something attached to faith.

Shi'ite Islam originated as a political movement supporting Imam Ali as the rightful leader of the Islamic state. The legitimacy of this claim, as initially envisioned by Imam Ali's supporters, was based on Muhammad's alleged designation of Imam Ali as his successor, Imam Ali's righteousness, and tribal customs, making him closely related to the Prophet. Imam Ali was murdered in 661, and his son, Imam Husayn, was killed in 681 by the army of Yazid I. The second Umayyad Caliph at Karbala (today in Iraq) was a seed of the Shi'a. It restored to religion the motive of passion, which has thoroughly penetrated Shi'ism (van Donzel 1994: 412).

In the mid $15^{\text {th }}$ century, the Safavids of Iran adopted Shi'a Islam, and their movement became highly millenarian in character. In 1501, under their leader Ismail I, the Safavids seized power in Tabriz, which later became their capital. Ismail was proclaimed shah of Iran. The rise of the Safavids marks the reemergence of a powerful central authority in Iran within geographical boundaries attained by former Iranian empires. The Safavids declared Shi'a Islam the state religion and used proselytizing and force to convert the large majority of Muslims in Iran to the 
Shi' a sect. ${ }^{2}$ At present, a large portion of the world's Shi'a lives in the Middle East. Shi'a Muslims constitute a majority in Yemen, Azerbaijan, Iraq, Bahrain and especially Iran, where $90 \%$ of the population is Shi'a, giving it the highest percentage of Shi'a Muslims of any country in the world. In Lebanon, Shi'ites form a plurality, and they remain significant minorities in Afghanistan, Syria, India, Pakistan, Turkey and Yemen. Among the small Persian Gulf states, Qatar, Kuwait $(\sim 30 \%)$ and the United Arab Emirates $(\sim 16 \%)$ also have significant Shi'a minorities, as does the Eastern Province $(\sim 33 \%)$ of Saudi Arabia (Simon, Mattar and Bulliet 1996: 1652 1653). According to Marcinkowski (2005: 17), about $20 \%$ of India's Muslim population is Shi'a, and significant Shi'a communities exist in the coastal regions of West Sumatra and Aceh in Indonesia. ${ }^{3}$ Shi'a presence is negligible elsewhere in Southeast Asia, where Muslims are predominantly Shafi'i Sunnis.

Some Shi'ite Muslims also established communities outside the Islamic countries including Thailand. Although they are a minority among Muslims, they have had powerful and close relations with Thai society for more than four hundred years.

\footnotetext{
${ }^{2}$ See Tabatabai (1989: 66). Shah Ismail I announced that the Ithna Ashari of "Twelver" from Shi' ism was to be the official religion of the newly established group in 1501 A.D.. As previously noted, Ithna Ashari Shi'ism lay at the heart of power of the Safavid leaders, their claim to be the representatives on earth of the $12^{\text {th }}$ imam or Mahdi, the last Shi' ite imam. See also Savoy (1980: 27).

${ }^{3}$ During the 1980s and 1990s, many Malaysians and Indonesians (mostly former Sunnites) were found at the theological study center of Qum in Iran. See Marcinkowski (2005: 17).
}

The main objective of this article is to explain and discuss the status and development of Shi'ite Muslims in Thailand from the establishment of their first community in the late $16^{\text {th }}$ century to the present day.

\section{Muslims in Ayutthaya, the former capital of Thai Kingdom}

Muslim people in Ayutthaya had contact with the lands of Southeast Asia by sea trade routes from Africa, Arabia, and Persia via India more than a thousand years ago due to $\mathrm{Siam}^{4}$ 's location on the international sea trade route from Iran to China. They established communities in a port of Siam before the $16^{\text {th }}$ century A.D. According to The Book of Duarte Barbosa (Barbosa 1967: 164-165), the record of a Portuguese traveler in the early $16^{\text {th }}$ century, several Muslim merchants from Arabia, Iran, India, Malaya and the Indonesian archipelago joined in the foreign trade with Chinese and local people in the western seaports of Ayutthaya, the former capital of the Thai Kingdom from the $15^{\text {th }}$ to the $18^{\text {th }}$ centuries.

In The Suma Oriental of Tomé Pires (Cortesao 1990: 109), Tomé Pires, another Portuguese traveler, notes the settlement of Muslims of many nationalities including Arab, Persian, Bengali, Kling (Muslims from southeastern India), and Chinese in the Siamese seaports. Fernao Mendes Pinto (1904: 63-65), a Portuguese traveler who passed through Siam in the mid $16^{\text {th }}$ century, wrote about two Turkish marshals who lived in Ayutthaya and led foreign troops to join the Siamese army in

\footnotetext{
4 "Siam" means the Ancient Thai Kingdom.

This term was used in many documents during the Ayutthaya and early Rattanakosin periods.
} 
1547-1548. He also remarked that there were seven mosques of the Turks and the Arabs, and about 30,000 households of the Moors in the capital of Siam. So it was possible that Muslim people had established communities in many Siamese cities before the $16^{\text {th }}$ century.

Ayutthaya, the capital of the Thai Kingdom from A.D. 1350 to A.D. 1767, is situated in central Thailand on an island surrounded by natural rivers which helped protect the city from enemies and connected the capital with the hinterland and sea through river branches. The city of Ayutthaya was the center not only for Thai administration but also for trade and commerce. For some four hundred years, the commerce of the Eastern world passed through Ayutthaya. Goods from those great trading empires, China and Japan to the east, and India and Persia to the west went back and forth through Siam. Thus, Muslims from different nations traveled into the land for trade and other purposes, and settled in the land of opportunity.

The Siamese referred to the various Muslim groups as a whole by the term khaek. This term was used to refer to people from the lands west of ThailandIndia, Iran, Arabia, and the Middle East, whose people were mainly Islamic. Other nationalities from the West who were not Muslims but were not Europeans also fell under the category khaek, for example the Hindu. Later on, the Malays were also called khaek. From documents and other evidence in Thai history, the khaek immigrants in Siam could be separated into two groups. The first group consisted of those of the Islamic religion or so called Muslims, e.g. khaek Malay, khaek Cham, khaek ya wa (khaek Java), khaek Makassar and khaek chao sen (khaek man khon or the Shi'ite Muslims). The other group consisted of people who practiced other religions, e.g. khaek Brahman, khaek Hindu and khaek Sikh. According to the Royal Institute (1969: 2273 - 2272), the Siamese used the term khaek in the sense of 'foreigners,' and the term later meant the people from the West who were not Europeans.

There were three large groups or communities of Muslim in Ayutthaya. The first was the communities on the banks of the Chao Phraya, the greatest river of Thailand, opposite the south and southeast city walls. The second group was the communities inside the outer city walls near canals or the river, and the third group was the communities inside the city walls. However, there were other Muslims who spread to other areas, but mainly near the river or canals, or in trading areas or markets that were in contact with the urban communities.

\section{Muslims of the Cham Malay groups and from the Southeast Asian} Archipelago who resided in communities along the banks of the Chao Phraya opposite the south and southeast city walls were Muslims of Malay race or Muslims from the States in the Malay Peninsula, the Muslims of Makassar State in the Indonesian archipelago, and the Cham Muslims. Chularatana (2007: 94) notes that these Muslims consisted of both traders and political refugees that migrated into the country, so they were of varied professions and classes.

Pongsripian (1985: 7) states that the Muslims from the Malay Peninsula who settled in Siam ranged from merchants to slaves. $^{5}$ Moreover, there were also

\footnotetext{
${ }^{5}$ According to The Suma Oriental of Tomé Pires (Cortesao 1990), some merchants from
} 
prisoners of war from occasional conflicts between the Muslim states in the Malay Peninsula and Siam. ${ }^{6}$ Most Malay merchants were in waterside communities for easy access to trade. Others resided outside of the city walls, in the south, adjacent to the Cham communities. As mentioned in A History of South-East Asia (Hall 1994: 346-347), the Muslims from the Southeast Asian archipelago states, namely Java and Makassar, were merchants and political refugees because those Muslim states were invaded by the Dutch or power struggles among themselves.

The Cham or khaek Cham originated from the south of Vietnam in the area of the triangle at the mouth of the Mekong. A group of Cham migrated to Ayutthaya in the early Ayutthaya period, with communities at the mouth of Khu Cham Canal, or in old documents Patha Khu Cham meaning "the village of the Cham,"7

Pattani, Kedah, Kelantan and Terengganu traded with the Chinese and the Moors at the seaports of Siam. In The Suma Oriental (Lach and Flaumenhaft 1965: 28), it is noted that some goods from Malacca, which were traded in Siam, included Malayan men and women slaves. In The Chevalier de Chaumont and the Abbé de Choisy Aspects of the Embassy to Siam 1685 (Smithies 1997: 84), it is stated that most of the Malays in Siam were slaves and laborers.

${ }^{6}$ Some Muslim kingdoms in the Malay Peninsula such as Pattani and Kedah had been the tributary states of Siam. When they tried to overthrow the influence of Siamese power, the Siamese king would send their troops to subdue and forcibly move some Malay people to Ayutthaya. See Teeuw and Wyatt (1970: 228-235)

${ }^{7}$ Patha, a Cambodian word, means camp or village. Thus, Patha Khu Cham is the village of Cham people. It was cited in Royal Chronicles of Ayutthaya, Luang Prasert located in the south of the city of Ayuthaya near Wat Phut Thai Sawan. ${ }^{8}$ This area was considered one of the four largest markets around the capital city. ${ }^{9}$ According to Hall (1994: 218) and Scupin (1980: 68), the Cham people came into Siam periodically, partly to trade and partly to escape political problems because the Kingdom of Champa was invaded by Vietnam at the end of the $16^{\text {th }}$ century, forcing a number of Cham people to flee to Java, Malaya, Cambodia and Siam. Moreover, the Cham that migrated to Cambodia were taken prisoner when the Siamese army invaded Cambodia. ${ }^{10}$ When

Version and Kromphra Paramanuchit Version and Northern Thai Chronicles, Phra Wichian

Preecha (Noi) “พระราชพงศาวดารกรุงศรีอยุธยาฉบับ

หลวงประเสริฐและฉบับกรมพระปรมานุชิตและพงศาวดาร เหนือฉบับพระวิเชียรปรีชา (น้อย)" (1961b: 4) that in 1409 A.D. King Ramracha (1395-1409 A.D.) ordered the arrest of Okya Maha Sena (the Minister of State) for his opposition, but he was able to escape by crossing the river to Patha Khu Cham. Later, he supported King Nakharinthrathirat, the cousin of King Ramracha and the ruler of the city of Suphan Buri, to fight in removing his cousin from the throne. After King Nakharinthrathirat ruled the kingdom, he banished his cousin to live in Patha Khu Cham. There have been Muslim communities in the area of Patha Khu Cham until the present time. See also Kongchana (1999: 71)

${ }^{8}$ Its name means "the Temple of Lord Buddha of the Heavens".

${ }^{9}$ The four famous floating markets around the city of Ayutthaya were the Namwon Bang Kra Cha Market in front of Phranang Choeng Temple, the Pak Khlong Khu Cham Market near the Cham community, the Khu Mai Rong Market and the Pak Khlong Wat Doem (A Yo Thaya Temple) Market near the Chinese temple. See Pongsripian (1985: 3)

${ }^{10}$ The Cham Muslims originated in the kingdom of Champa in the south of present day Vietnam which had been invaded by the 
more Cham refugees arrived, the communities expanded to both sides of the Khu Cham Canal. According to Chularatana (2007: 94), the Cham communities were close to the Muslims from Malaya and Makassar as they were Sunni Muslims of the same sect.

Foreign evidence during the reign of King Narai (1656-1688 A.D.) of Siam indicates that this group of Muslims was the largest (La Loubère 1969: 112). The French missionary, Nicolas Gervaise (1989: 58), who came to Ayutthaya during the reign of King Narai in 1683, recorded that the Malays outnumbered other Muslim groups in Siam and that this group of Muslims were merchants, shipping crew, craftsmen, farmers, and civil servants. The merchants and shipping crew were connected, as many Muslim merchants were ship masters, since the Malays, like the Chams, were also expert in shipping (Chularatana 2007: 96).

In The Testimony of King Uthumphon ${ }^{11}$ (Pongsripian 1985: 7), it states that the Javanese-Malay khaek came by ship to trade with Siam regularly every year.

Vietnamese during the $14^{\text {th }}-15^{\text {th }}$ centuries. They were forced to migrate from their homeland to the neighboring countries. Some of them migrated to Cambodia and set up communities in Kampong Thom and Kampong Cham near the Mekong. They were forcibly moved to Ayutthaya when Siamese troops invaded the kingdom of Cambodia in the $15^{\text {th }}$ century. See Kongchana (1999: 71), Whitaker (1973: 73) and Scupin (1980: 68)

${ }^{11}$ King Uthumphon was the younger brother of King Ekkathat, the last monarch of Ayutthaya. After the fall of Ayutthaya to the Burmese army, King Ekkathat died but his brother was caught and forcibly moved as a war prisoner to Burma. Later, he was examined about the story of Ayutthaya which was recorded in the testimony.
Pongsripian (1985: 7) also states that the area of the mouth of the Khu Cham Canal was the location for Muslim merchants from Java and Malaya selling beetle nuts, rattan, other baskets, and goods from the south. Their customers consisted of Chinese, khaek, French, English, Dutch and Portuguese merchants. Another group of Muslims were Cham craftsmen who wove materials and mats, the Malays who made cabin ropes from coconut husks and welded boat anchors to sell to foreign ship captains. Another group of Muslims must have been farmers because there was production of local sustainable products such as rice and agricultural produce as well as animal husbandry. ${ }^{12}$

In Law of the Three Seals Volume I (Khurusapha 1962: 308), it is noted that another profession of this group of Muslims was civil service, as evidenced in Law of the Military and Provincial Hierarchies $^{13}$ which mentions the Krom Asa Cham (Cham Volunteer Corps) as a division of the Ministry of Defense with Phraya Ratchawangsan as chao $\mathrm{krom}^{14}$ (the division chief), in charge of the Cham volunteers consisting of Muslims of Cham and Malay descent. Some of the Muslims in this community were civil servants in the capital city. The Testimony of King Uthumphon (Pongsripian 1985: 2) mentions that within the area at the mouth of the Khu Cham Canal, there was an important

\footnotetext{
${ }^{12}$ Kongchana (1999: 77) explains that the Cham communities in the Ayutthaya period which were situated near the Khu Cham Canal, were farming society. They grew floating rice on the banks of the canal near their villages.

${ }^{13}$ Law of the Military and Provincial Hierarchies (พระอัยการตำแหน่งหน้าทหารหัวเมือง) is a regulation in the Ancient Laws of Ayutthaya. ${ }^{14}$ The ranks of Ayutthaya bureaucrats from high to low consist of Chaophraya, Phraya, Phra, Luang, Khun, Muen, Phan.
} 
tha nam (river ferry) called Tha Nam Phraya Ratchawangsan where was used to cross between the south side and inside the capital. The ferry was located near the house of Phraya Ratchawangsan, the division chief of Krom Asa Cham, who was in charge of the Cham communities in Ayutthaya. Some of the Cham and Malay Muslims who were civil servants in the Krom Asa Cham must have used this ferry to travel between inside the city walls and their communities at the Khu Cham Canal.

2. Khaek thet groups, Muslims from Pattani and groups of Muslims with small enterprises settled in communities just outside the city walls, near canals or rivers to the south of the city island. They were khaek ta ni (Pattani Muslims) and khaek thet. The khaek thet might have been Sunni Arabian or Indian Muslims who resided in the Tha Ka Yi area, the old khaek area of Ayutthaya. They built houses on the capital city side in the east and south, as mentioned by Dewongsa (1987: 19). This group of Muslims consisted of both small merchants selling in the city markets and those selling from ships anchored around Ban Nam Won Bang Kra Cha Market.

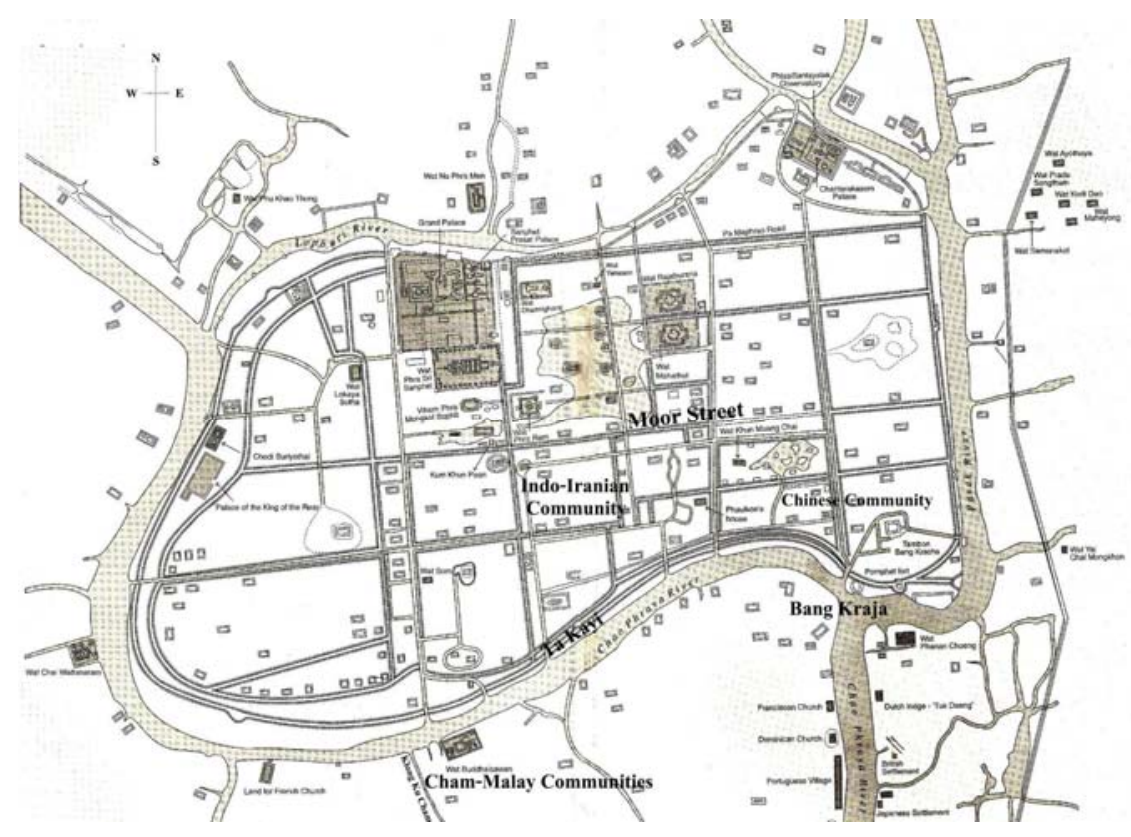

Figure 1: Map of Muslim Communities in Ayutthaya City

(Source: Garnier 2004: 146-147) 
The area of Ban Nam Won Bang Kra Cha Market was where the Chao Phraya and the Pa Sak joined to the southeast of the city of Ayutthaya. It was the route local merchants to ship merchandise from the north to sell, and foreign merchants would bring their ships to offload and buy local goods. The Muslims in this area were mainly merchants and craftsmen, building their homes along the Chao Phraya. The merchants would trade with foreign ships and at the same time buy their goods to sell in the city markets. ${ }^{15}$ The craftsmen who were khaek thet and khaek Malay made cabin ropes from coconut husks and welded boat anchors to sell to foreign ship captains. Others were khaek ta ni who lived near Wat Lot Chong and were weavers of silk and cotton material, both plain and patterned, which they sold.

3. Indo-Iranian Muslims resided inside the city walls and consisted of Iranian, Arabian, Turkish and Indian Muslims. They were of mixed ethnicity and culture and were known as "Indo-Iranian Muslims". However, according to Chardin (1988: 126), it is difficult to determine the real ethnicity of this group because Iranwas a place of many races that were already mixed to a certain extent, ${ }^{16}$ as were the Muslims in India who were mixed between locals and Muslims from Arabia,

\footnotetext{
${ }^{15}$ Pongsripian (1985: 15) cited that there were khaek thet (Muslims from the country west of Siam) shops at the Chi Kun Market in the city wall where jewellery and brasses were sold.

${ }^{16}$ According to Chardin (1988: 26), Iran was a place of many races that were already mixed to a certain extent. The major races of Iranians are the Persian, the Kurdish, the Gilani, the Mazanderani, the Lori and the Baluchi, and the major non-Iranian races are the Semitic or Arabs and the Turkish. See also Limbert (1987: 21)
}

Turkey and Iran (Datta, Raychaudhuri and Majumdar 1987: 451-452, 469).

According to Cole (1988: 22), Indian Ocean trade routes linked the Persian Gulf with southern India, encouraging a migration of people and ideas between the two areas. Iranian nobles, administrators, military men, and literati flooded into the Deccan during the $13^{\text {th }}$ century. Diplomatically and in its elite culture, southern India became a dependency of Iran under the Safavid Empire in the $16^{\text {th }}$ century. The longest-lasting of the Shi'aruled states in the Deccan was the Qutab Shahi kingdom of Golconda (1512-1687). Before this kingdom came into power, the Nizam Shahi kingdom of Ahmadnagar (1508-1633) and the Adil Shahi kingdom of Bijapur, the Shi'ite Iranian diasporas had spread along the Deccan and the Coromandel coast of Southeastern India.

The Qutab Shahi kingdom of Golconda served thus also as an important gateway to Southeast Asia. By the second half of the $16^{\text {th }}$ century, there existed intensive trade links between Golconda's main port at Masulipatum and Siamese Tenasserim, as mentioned by Alam (1959: 169-87) and Arasaratnam (1984: 113-35). The sea trade route from southeastern India to the western seaports of Siam not only fostered the politico-economic relations between the Shi'ite Deccan states and Siam, but also supported the expansion of Shi' ism to the Buddhist Kingdom of Ayutthaya.

\section{Shi'ite Indo-Iranian Muslims during the Ayutthaya period}

Western documents generally call the Indo-Iranian Muslims in Thailand "Moors" which was the term the Portuguese and Spanish used for Muslims or people of the Islamic religion who came 
from North and East Africa, the Middle East, Central Asia, and India. It was a general term that did not distinguish between race, region or religious sect. When other Westerners came to Asia later, they also used the Portuguese and Spanish term "Moors".

The word 'Moors' in Western documents therefore included the Muslims from West Asia and sometimes also Muslims from India. In the account of the Chevalier de Chaumont, the first French envoy sent by King Louis XIV to King Narai's court in 1685, the name "Moors" included Turks, Persians, Moguls, Golcondans and Muslims from Bengal.

The Siamese during the Ayutthaya period called the Indo-Iranian Muslims by various names, for instance, khaek chao sen, khaek ma ngon, khaek yai and khaek thet. The term khaek chao sen was used by the Siamese to denote Muslims of this sect, the word chao sen being the name of Imam Hussein, one of the most important imams of Shi'ite Islam. The Siamese called this group khaek chao sen because the Indo-Iranian Muslims during the Ayutthaya period were Muslims of the Shi'ite sect. According to Smithies (1997: 84) and Gervaise (1989: 175), westerners recorded that the Moors in Siam were a different sect of Muslims from the Malay as the Malay were of the Shafis school of Laws from the Sunni sect and the Moors in Siam mostly were Ithna-asharis or Imamiyya, one of the Shi'ite Muslim sects.

According to Kanjanakphan (1974: 49), the term khaek ma ngon comes from the word "Mogul" or "Mughal" because the Siamese thought that this group of Muslims were khaek Mughal (but actually the Mughal Indians were Sunni Muslims) or they were using the Western terms
Moors, Mughals or Mouros. ${ }^{17}$ Ma ngon may also have come from the word "Mahol" which the Iranians used to refer to Indian Muslims, as evidenced in Safinai ye Sulaimani "the Ship of Sulaiman" (Rabi 1972: 95), a travel account of the Iranian envoy from the Safavid Shah Sulaiman of Iran to King Narai's court in 1685. It records that the Mahols were Shi'ite Muslims from India. Thus the term khaek ma ngon probably meant the Indo-Iranian Shi'ite Muslims. This term appears in Poems on Festivals (กาพยห่อโคลงว่าด้วย งานณขัตถกษ์) by King Rama II (Khurusapha 1961a: 28) which mentions the Muharram Ceremony, a ceremonial procession in memory of the martyrdom of Imam Hussein of the khaek chao sen or khaek ma ngon in Siam. According to Thipakorawong (1979: 131), the Siamese Minister of Trade and Commerce, called the khaek chao sen or Shi'ite Muslims khaek ma hon or khaek ma ngon.

According to Kaempfer (1987: 4), Gervaise (1989: 39), Choisy (1993) and Smithies (1997: 165), this group of Muslims was said to reside inside the city walls near the Chinese district, with houses and shops along the large brick road which led to the Royal Palace. The Indo-Iranian Muslims had their communities in the commercial district of Ayutthaya, from the Chinese gate to the gate south of Tha $\mathrm{Ka} \mathrm{Yi}^{18}{ }^{18}$ The Testimony

\footnotetext{
${ }^{17}$ Portuguese and Spanish always call the Muslim people "Mouro".

${ }^{18}$ Book of Court Customs in the Ayutthaya Period (ตำราแบบธรรมเนียมในราชสำนักครั้งกรุงเก่า) mentions that the two Muslim officials, Khun Kocha Ishak and Khun Raja Setdhi, took responsibility for overseeing and protecting the Muslim district from Pratu Chin (the Chinese Gate) to Pratu Tai Tha Ka Yi (the Gate South
} 
of King Uthumphon describes the area where these Muslims lived as almost in the center of the capital city, and because the Siamese called these Muslims khaek thet, khaek yai or khaek chao sen, the landmarks in the area of these communities bore their name, for instance, Ban Khaek Yai Chao Sen (the village of khaek yai chao sen), Khlong Pratu Thet (the canal of khaek thet gate) and Thanon Ban Khaek Yai (ban khaek yai street). ${ }^{19}$ In this area, there were houses and shops along the roads that were called "bazaars" which were depicted in Western paintings as rows of shops parallel to the road. This group of Muslims also built religious places in the communities ${ }^{20}$ as evidenced in the account of the French during the reign of King Narai which mentions that the Moors performed their religious rites in this area.

Nowadays, there are few traces of the Shi'ite Muslim presence in Ayutthaya

of Tha Ka Yi). See Book of the Siamese Court Customs Volume 2 (ลัทธิธรรมเนียมต่าง ๆ เล่มสอง), 1972, p. 519

${ }^{19}$ It was probably called Shikun Street, a name which came from Sheikh Street, meaning the Street of Scholars.

${ }^{20}$ Phraya Boran Rajchatanin, the Lord Lieutenant of Ayutthaya district in King Rama V's reign, called thung khaek (the Muslim pasture) which stood in the area of the Phranakhon Si Ayutthaya Rajabhat University nowadays. There are some ruins of the building in it such as an Indo-Iranian style arc bridge and a pedestal of the religious building. See $A n$ Explanation of the Ayutthaya Map with Phraya Boran Rajchatanin's Opinions Concerning the Art and Historical Background of Ayutthaya and Phichit (อธิบายแผนที่พระนครศรีอยุธยากับคำ วินิจฉัยของพระยาโบราณราชธานินทร์เรื่องศิลปะและภูมิ สถานกรุงศรีอยุธยาและจังหวัดพิจิตร) $, 1971, \mathrm{pp} .72-$ 73. because the city was destroyed and burnt in the battle between Ayutthaya and Burma in 1767 A.D. However, we are able to find some ruins of buildings such as an Indo-Iranian style arch bridge and the pedestal of a religious building in the area of the Phranakhon Si Ayutthaya Rajabhat University in Ayutthaya city.

The main factor that persuaded the Court to permit this group of Muslims to settle down inside the city walls, along with the Chinese, was the importance of the community to local and international trade. The Muslims inside the city walls were merchants who bought luxury goods to sell, such as Persian carpets, rose water, brocades, jewelry and gold ornaments. ${ }^{21}$ These goods were expensive and bought by the rich, courtiers, members of the royal family and the King, who resided within the city walls. These merchants must have been selling to rich and powerful people in the capital city from the beginning, so they received special treatment to set up their communities in the important areas of Ayutthaya. Gervaise (1989: 63) points out that the Moor merchants played as prominent a role as the Chinese merchants in the commerce of Siam. As noted in Na Pombejra (1990: 130 ), in the $17^{\text {th }}$ century, the rulers and members of the royal family, plus some of

\footnotetext{
${ }^{21}$ The Dutch trade records cited that clothes and golden treasures from Persia were highly valued in the Ayutthaya market. See Suttakul (1970: 61). The records of French merchants mention that some of the presents which were given to Constantine Phaulkon, King Narai's Greek counselor, also included Persian wine, rose water and Persian fruits. See Collected Historical Data Volume 25 (Part 41-43), French Merchants' Records (ประชุมพงศาวดารเล่ม ที่ 25 ภาคที่ 41 (ต่อ) ถึงภาคที่ $42-43$, จดหมายเหตุพ่อค้า ฝรั่งเศส), 1968, p. 270.
} 
the khun nang, nobility, prospered by relying on foreign merchants to conduct this trade on their behalf. Thus, according to Andaya (1999: 135), as one of the two principal trading communities, the Muslim merchants, especially those from Persia and India, had a significant impact on the history of Ayutthaya.

This group of Muslims also worked in government, both in military and civil service. The ones in military service were in the Kong Asa Tang Chat (the Foreign Volunteer Corps) and the Royal Guards appointed by the King to work as special forces, possibly volunteers or foreign volunteers specifically employed for this purpose. ${ }^{22}$ Rabi (1972: 100) mentions that King Narai employed 200 Iranians from India to be his Royal Guards, whereas Guy Tachard, a French Jesuit priest who came to Ayutthaya for the first time in 1685 in the reign of King Narai, describes the welcome ceremony for the French diplomatic corps of Chevalier de Chaumont as including a company of Moor soldiers on horseback carrying spears on duty in the second level of the Royal Palace. In the fourth level of the Palace, in the two side halls, there were around 500 Persian Royal Guards (Tachard 1999: 166). The Indo-Iranian Muslim Volunteer Corps must have resided inside the city walls in the same

\footnotetext{
${ }^{22}$ Prince Damrongrachanuphap (1991: 42), the Minister of the Interior in King Rama V's reign, explained that the Kong Asa Tang Chat (The Foreign Volunteer Corps) consisted at first of foreigners who had had military skills, and volunteered in the Siamese army. Later, they were collected into the Kong Asa (The Volunteer Corps) which was sent into battle, and separated by nation, for example Kong Asa Nippon (The Japanese Volunteer Corps) and Krom Asa Cham (The Cham Volunteer Corp Division).
}

manner as other Muslims of the same race, as they had to work in close contact with the King and also perform religious rites with their own communities.

As for those in the bureaucracy, most were attached to the Krom Tha Khwa, the Siamese Department of Western Maritime Trade Affairs, and also resided inside the city walls. Krom Tha Khwa is a commerce and foreign communication section under the Krom Phra Khlang (the Department of Trade and Treasury), with responsibility for commerce, the merchant marine, and foreign affairs. However, Krom Tha Khwa had another important duty: the supervision of foreign subjects consisting of Muslims, Hindus, Armenians and baptized Christians. Therefore, even if the majority of officials in the Krom Tha Khwa were Muslims, there were officials and experts of other nationalities in these positions, e.g. Portuguese, Hindu Indians and Armenians. The majority of these officials were the groups that came originally from lands west of Siam or were related to the Westerners, for example, those who were baptized Christians.

According to the Chronicle of the Bunnag Family, a record of history of officials in the Bunnag family, a powerful family in Siam in the early Rattanakosin or Bangkok period, ${ }^{23}$ Sheikh Ahmad, as ancestor who was a Shi'ite Iranian, came to trade in Siam with his younger brother Muhammad Sa-id in 1603 A.D., during the reign of King Ekathotsarot (1605-1610) and began to serve in the civil service in the reign of King Song Tham (1610-1628), the younger son of King Ekathotsarot. The

\footnotetext{
${ }^{23}$ Bunnag was the most powerful family in Thailand in the $18^{\text {th }}-19^{\text {th }}$ century. Some of the members of this family held high ranks in the Thai government for a hundred years into the early Bangkok Era.
} 
book states that Sheikh Ahmad assisted in the activities of Krom Tha, the Foreign Trade Department, and was later appointed head of Krom Tha Khwa as chularajmontri, ${ }^{24}$ the head of Muslim communities in Ayutthaya. This same book also mentions that Sheikh Ahmad was a very close personal friend of Phraya Maha Amat, ${ }^{25}$ who later became King Prasat Thong (1629-1656), the king of Siam after King Songtham. According to Chularatana (2003: 156), all of the chularajmontri men of Siam before the democratic revolution in Thailand in 1932 were descended from Sheikh Ahmad and the Krom Tha Khwa administration was monopolized by Shi'ite Muslims of his family.

During the $16^{\text {th }}$ and the $17^{\text {th }}$ centuries, the shahs of the Safavid dynasty ruled Iran. In those days, they wanted to expand their influence and so built up communities of Shi'ite Iranians in India. According to Sykes (1969: 175-77) and Floor (2001: 180-81), Shah Abbas I (1587-1629) of Iran had a very close relationship with the Emperor of the Mughal dynasty. At the same time, the shahs of the Safavid dynasty also supported the Shi'ite states of India, such as Golconda, Bijapur, and Ahmadnagar, by sending different experts into the civil service in those states. Many Iranians married local women, mixing races and cultures. This group of IndoIranian people, especially Indo-Iranian

\footnotetext{
24 Thipakorawong (1979:12) states that chularajmontri compounds of an Arabic word shura means an Islamic council and a Sanskrit word montri means a King's counselor so that chularajmontri means the King's Muslim counselor. He was the head of Muslims in Thailand as Sheikh al Islam.

${ }^{25}$ Thipakorawong (1979:14) notes that Phraya Maha Amat was lord of the Ministry of Defense.
}

Muslims, had important roles in the building the trading networks and linking Iranian politics, religion, society and culture to Eastern lands. Shah Abbas I also expanded trade with China, having diplomatic ties with the Chinese court, to the point of bringing Chinese craftsmen to build chinaware factories in Iran. Silk from Persia was widely distributed as far as the palaces of the Shoguns of Japan. It was during the time of Shah Abbas I that a large number of Iranians came to trade and expand their influence in Southeast Asia.

Sheikh Ahmad traveled to Ayutthaya under the context of political, economic, religious and cultural expansion by the Iranian court during the Safavid dynasty. At the same time, an important supporting factor was that the Kingdom of Ayutthaya had developed into a cosmopolitan port which welcomed the migration of people of other nationalities and other religions. The Kingdom of Ayutthaya had become a stronghold for Shi'ite Muslims from Iran and India who came to expand trade and Shi'ism.

Moreover, there were religious institutes called Kudi Thong or the Golden imambara within the community to hold ritual ceremonies and to act as community centers. Imambara in Urdu (Indian Muslim language) or imamsadeh in Farsi means the house of the imam. The original imambara in Ayutthaya looked like some styles of local architecture in the northeastern provinces of Iran near the Caspian Sea in Mazanderan and Gilan. Sheikh Ahmad probably came from a town named "Kunni" in the northeastern part of Iran near the Caspian Sea (Chularatana 2004: 94-105), and he probably built an imambara in Ayutthaya in the same style as in his homeland. The imambara buildings in Siam remained 
under the patronage of noblemen in the family of Sheikh Ahmad until Ayutthaya was destroyed by the Burmese in 1767 A.D. During the reign of King Rama I, the first King of the Bangkok era, it was rebuilt in the Shi'ite Muslim community in Thon Buri province on the western side of the Chao Phraya near Bangkok.

The imambara building is not only the center of the Shi' ite Muslim community, but also the center of taziyat, the most important ritual of Shi'ite Muslims in Thailand. The taziyat or ashura ceremony is performed to commemorate the martyrdom of Imam Hussein, the grandson of the Prophet Muhammad. He was killed by Yazid I, the second Caliph of the Umayyad in 680 A.D. Shi'ite Muslims, who highly respect Muhammad's descendents as the holy family, perform taziyat in the month of Muharram, the first month of the Islamic lunar calendar. Every year they mark the martyrdom of Imam Hussein for ten days. They wear black, the color of mourning, and make a procession which represents the epic of Imam Hussein and his followers in Karbala.

Rabi (1972) claims that King Narai (16561688 A.D.) and his companions hid in the taziyat procession of the Shi'ite Muslims in Ayutthaya to seize the Royal Palace and arrest his uncle, the former King. According to the descriptions of the French Envoy who was sent by King Louis XIV to the Siamese court of King Narai in the $17^{\text {th }}$ century, the taziyat procession was a famous and well-known Moorish ceremony in Siam. 
The prelude of the Bunnag family: The Shi'ite Muslims in the transition period

The Shi'ite Iranian Muslims

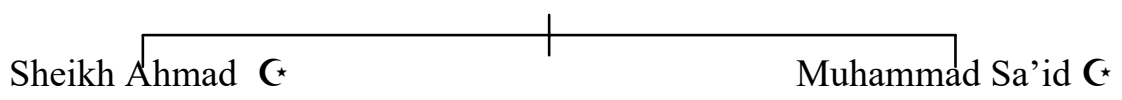

(Ok Phra Chula)

(Ok Ya Bawonratchanayok)

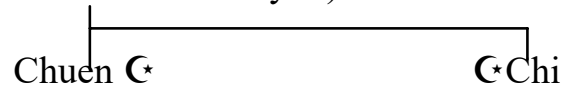

(Ok Ya Worachetphakdi; acting Chula) (Ok Ya Aphairacha; Samuhanayok)<smiles>CC(C)[SeH]</smiles>
(1630-c.1683) (Ok Ya Chamnanphakdi) (Samuhanayok)

Chai $\leftarrow+$

(Chaophraya Phetphichai)

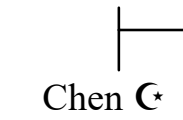

(Phraya Chula)

(Phraya Wichitnarong)

Konkaew C*

(Phraya Chularajmontri)

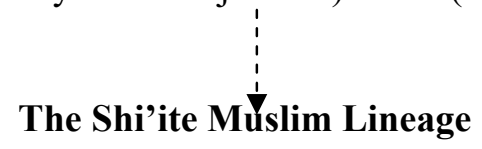

(Ok Ya Si Chaihannarong)

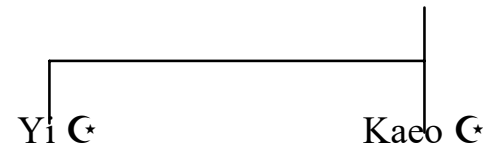

(Ok Phra Chula)
Aqa Muhammad C (Ok Phra Si Naowarat)

(Governor of Tenasserim)

Muhammad Sa'id C*

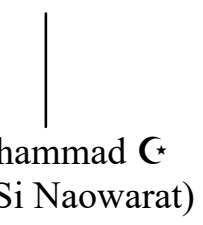


After King Narai died, Phra Phetracha, a high-ranking courtier-official, usurped the throne and founded the Ban Phlu Luang dynasty in 1688. The Ban Phlu Luang kings formed new diplomatic policies to limit contact with foreigners and control the roles of Muslims and Christians in the kingdom (Chularatana 2003: 244-245). King Borommakot (1733-1758) emphasized the Ayutthaya kingdom as the center of Theravada Buddhism. In 1751, King Kirti Sri Rajasinha of Kandy sent his envoy to the Siamese king to invite Siamese monks to perform the ordination ceremony for the Kandyan Sangha, which had deteriorated as a result of European expansion since the late $16^{\text {th }}$ century. At the end of 1751 , King Borommakot sent a group of senior monks to Sri Lanka to re-establish Buddhism. Because of this, Buddhism in Sri Lanka is called Siamwong Buddhism. ${ }^{26}$

To solidify his reputation as a true Buddhist king, he ordered renovations on many royal temples in Ayutthaya and concentrated on Buddhist royal ceremonies, for instance the annual pilgrimage to Phra Phutthabat, the Buddha's footprint, in Saraburi, a province north of Ayutthaya. Moreover, he strictly controlled the expansion of Islam and Christianity by emphasizing the royal regulation of

${ }^{26}$ Buddhism in Sri Lanka had suffered a decline under Portuguese rule between 1594 and 1612. The movement for a Buddhist revival in Sri Lanka dated from about the second decade of the $18^{\text {th }}$ century under the patronage of the Kandyan kings. The Kandyan embassy left Sri Lanka in 1750, arrived in Ayutthaya in May 1751 and left toward the end of this year accompanied by eighteen monks led by Phra Ubali and Phra Ariyanamuni. Sri Lankan monks who were ordained by Siamese monks of the Buddhist mission formed a sect known as Siamwong or Ubaliwong. See Lailert (1972: 279-282) religious missions prohibiting Thai, Mon and Lao in Siam from professing mistaken beliefs. ${ }^{27}$ As mentioned in The Laws of the Three Seals (Khurusapha 1962: 98-99) and Lailert (1972: 283), those Thai, Mon or Lao who deserted the holy Siamese religion for Christianity and Islam would be subjected to capital punishment. Lailert (1972: 287) also mentions that during the Ban Phlu Luang period, Buddhism was used to create a sense of identity and a sense of unity within the kingdom.

Some of the Sheikh Ahmad's descendants in the Siamese bureaucracy probably worried about the situation which had an effect on their stability, and then probably were pressed to convert to Buddhism. According to Thipakorawong (1979: 23), Phraya Phetphichai (Chai), the head of Sheikh Ahmad's family, converted to Buddhism in order to join the royal pilgrimage of King Borommakot to Phra Phutthabat in 1750. After Phraya Phetphichai (Chai) changed his belief and came back from Phra Phutthabat, he and his family succeeded in re-establishing their power and roles in the Siamese administration. Phraya Phetphichai (Chai), the head of the royal guard, was appointed to be Chaophraya Phetpichai, a highranking noble, and his second son, Sen, was put in the position of Chaophraya Mahasena, the master of the Ministry of Defense, during the reign of King Ekkathat (1758-1767). Chaophraya Mahasena (Sen) had a son with his second wife, named Bunnag who had close relations with Luang Yokkrabat Mueang Ratchaburi (the ruler of Ratchaburi), named Thong Duang, and he married Nuan, a younger sister of Nak, Luang Yokkrabat Mueang Ratchaburi's wife also. After Luang Yokkrabat Mueang

\footnotetext{
${ }^{27}$ The Laws of the Three Seals (กฎหมายตราสาม ดวง) (Khurusapha 1962: 98-99)
} 
Ratchaburi took control of Siam and crowned himself king, King Rama I (1782-1809), Bunnag became a highranking courtier-official of King Rama I. His family played a vital role in administering the Siamese kingdom from the early Rattanakosin period until the 1880s (Keat Gin Ooi 2004: 288).

It was possible that Chaophraya Phetpichai and some of his heirs applied taqiyah, the Shi'ite practice of dissimulation, to avoid the complicated problem with Ban Phlu Luang's policy. Among the followers of the different schools of Islam, Shi'ites are well known for their practice of taqiyah. In case of danger they dissimulate their religion and hide their particular religious and ritual practices from their opponents. ${ }^{28}$ Taqiyah might have been applied to maintain the positions of Sheikh Ahmad's family in the Siamese bureaucracy and to protect the Shi'ite community from the ethno-religious persecution during the Ban Phlu Luang's era.

Though Chaophraya Phetpichai and his younger son, Sen, converted to another religion, his eldest son, Chen, remained faithful to Shi'ism, his ancestors' faith. $\mathrm{He}$ was appointed to the position of Phraya Chula, the master of Krom Tha Khwa, in King Ekkathat's reign, and his son, Konkaew, was appointed to the position of Phraya Chula, the first chularajmontri in the Rattanakosin period, by King Rama I.

\footnotetext{
${ }^{28}$ According to Tabatabai (1989: 223), the practice of taqiyah is permitted if there is definite danger facing one's own life or the life of one's family, or the possibility of the loss of the honor and virtue of one's wife or other female members of the family, or the danger of the loss of one's material belongings to such an extent as to cause complete destitution and prevent a man from being able to continue to support himself and his family.
}

\section{The Shi'ite Muslims in the Rattanakosin Period}

After Ayutthaya was destroyed by the Burmese in 1767, some of the members of Sheikh Ahmad's family migrated to Bangkok, the new capital city of the Siamese Kingdom after Ayutthaya, and reestablished a new Shi'ite Muslim community on the banks of the Chao Phraya opposite the Grand Palace. The increasing power of the Bunnag family during the early Rattanakosin period sustained the stability of the Sheikh Ahmad's descendants. Konkaew, a descendant of Sheikh Ahmad and a cousin of Bunnag, was appointed to the position of Phraya Chularajmontri, the head of Muslim communities in Siam. Between 1782 and 1932, the Shi'ite chularajmontri men from Sheikh Ahmad's family continued to administer the Krom Tha Khwa with the support of the members of the Bunnag family who held influential positions in Siamese departments especially Krom Phra Khlang, the Ministry of Trade and Finance, which commanded Krom Tha Khwa as well. 


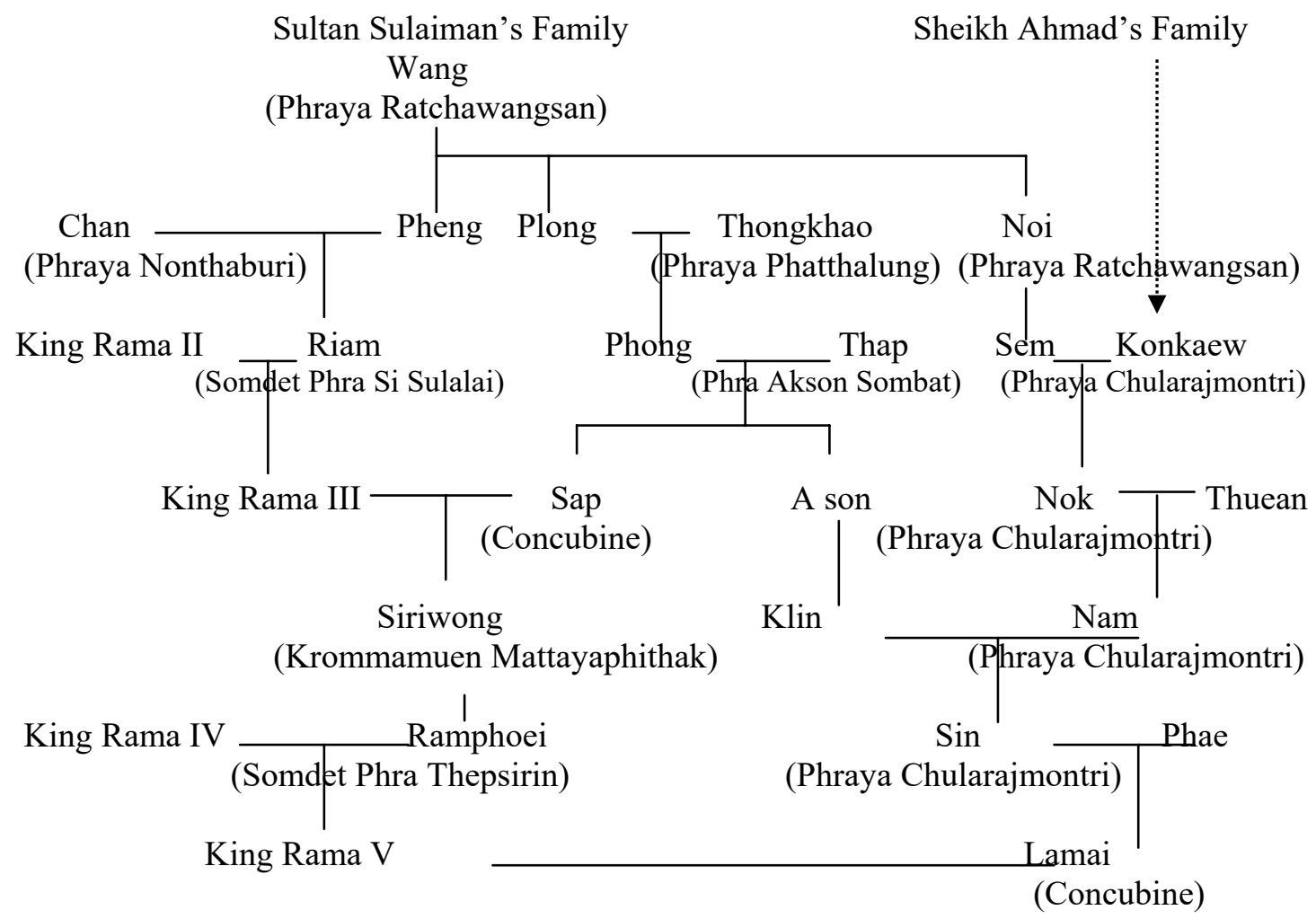

Figure 3: The connection between the Muslim families and the Chakkri Dynasty

(Source: Chularatana 2007: 250)

The Shi'ite chularajmontri men from Sheikh Ahmad's family not only had closed relations with the members of the Bunnag family but also had connections with the members of the Chakkri dynasty. Phraya Chularajmontri (Konkaew) married Sem, a daughter of Phraya Ratchawangsan (Noi), the master of the Siamese navy, a member of Sultan Sulaiman's family, Sunnite Iranian Muslim from Songkla. Sulaiman was a son of Dato' Mogol, an Indo-Iranian traveler from the Indonesian archipelago. Dato' Mogol was appointed to be the first governor of Songkhla by King Song Tham (Chalayondecha 1986: 130-32). After the usurpation of King Prasat Thong in 1629,
Sulaiman declared the independence of the Sultanate kingdom of Songkhla. He and his successors ruled Songkhla until the kingdom was invaded by Siamese troops in 1668. Some of their descendants migrated to Ayutthaya and were appointed to high positions in the Siamese bureaucracy especially Krom Asa Cham (Chalayondecha 1986: 130). Some of the members of Sultan Sulaiman's family were closely connected with the Chakkri dynasty and Sheikh Ahmad's family through marriage. Three of the Shi'ite chularajmontri men in the early Rattanakosin period, Konkaew, Thuean and Nam, married women from Sultan Sulaiman's family. Because of their 
relations with the members of the Chakkri dynasty and other powerful families in Siam, they were supporters of the head of Muslims including the Shi'ites and Sunnites in the central part of Siam.

\section{The thirteen Shi'ite Muslim Chularajmontri $^{29}$}

1. Ok Ya Bawon Ratchanayok (Sheikh Ahmad), chularajmontri (the king's supervisor) during the reign of King Prasat Thong

2. Phraya Chularajmontri (Kaew) during the reigns of King Prasat Thong and King Narai

3. Phraya Chularajmontri (Son) during the reigns of King Phetracha and King Thai Sa

4. Phraya Chularajmontri (Chen) during the reigns of King Borommakot and King Ekkathat

5. Phraya Chularajmontri (Konkaew) during the reign of King Rama I

6. Phraya Chularajmontri (Akayi) during the reign of King Rama I

7. Phraya Chularajmontri (Thuean) during the reigns of King Rama II and King Rama III

8. Phraya Chularajmontri (Nam) during the reigns of King Rama III and King Rama IV

9. Phraya Chularajmontri (Noi) during the reign of King Rama IV

10. Phraya Chularajmontri (Sin) during the reign of King Rama V

11. Phraya Chularajmontri (Sun Ahmadchula) during the reigns of King Rama V and King Rama VI

12. Phra Chularajmontri (Kasem Ahmadchula) during the reign of King Rama VI

${ }^{29}$ Chularatana (2007: 243)
13. Phra Chularajmontri (Son Ahmadchula) during the reign of King Rama VII

By the time of the Bangkok kingdom, the chularajmontri had become an official leader of all Muslims in Thailand. In the Bangkok period, there were nine chularajmontri men, all of whom were descended from the Shi'ite chularajmontri in the Ayutthaya period, and all of whom served under the Chakkri kings as highranking nobility in Krom Tha Khwa.

Following the Democratic Revolution in Thailand in 1932, there was no appointment of a chlarajmontri after the death of Phra Chularajmontri (Son), the last chularajmontri from Sheikh Ahmad's family, in 1936. It was not until the turmoil and disaffection of Muslims in Southern Thailand following General Pibun's forced integration policies, against which the rise of Malay separatism threatened the stability of the central Thai government that a new chularajmontri was hurriedly appointed (Aphornsuvan 2003: 20).

The Islamic Patronage Act of 1945 (revised in 1948) authorized the government to form the National Council of Islamic Affairs (NCIA) of Thailand, headed by an ex-officio chularajmontri. The chularajmontri is appointed directly by the King on the recommendation of the Minister of Interior, and can be removed only by the King. His tenure is for life (Aphornsuvan 2003: 21). ${ }^{30}$ The first chularajmontri in the democratic period was a commoner, Cham Promyong, a Sunni Muslim who was a member of the

\footnotetext{
${ }^{30}$ See also "The Islamic Patronage Act of 1945" in The Collected Laws of Islam (Bangkok: Nidhivedh, 1997), p. 12.
} 
People's Party and a senior government official in the Public Relations department at that time (Aphornsuvan 2003: 21). The Shi'ite Muslims in the Siamese administration lost their positions and the last three chularajmontri men after the Democratic Revelation were appointed from the Sunnites, the majority of Muslims in Thailand.

The Shi'ite population in the Rattanakosin period grew and some of their members moved to establish settlements in other areas. In 1950, Masjid Kudi Luang, the first Shi' ite Muslim community established in the early Bangkok period, moved from the banks of the Chao Phraya to a new place because they gave up their property for enlargement of the Thai Navy's head office, situated near their community. Today, there are four Shi'ite Muslim mosques in Bangkok, Masjid Kudi Luang, Kudi Charoen Phat, Masjid Dinfallah and Masjid Phadung Tham Islam. All of them are situated in the Thonburi district of Bangkok and they are also centers of Shi' ite Muslim communities in Thailand. There are around 6,000 to 7,000 Shi'ite Muslims in the Bangkok area, which makes them a minority group of Muslims. Most of them are descended from IndoIranian Muslim ancestors that settled in Thailand in the Ayutthaya and the early Bangkok periods.

\section{The Shi'ite communities and the new Islam impact}

The Islamic Revolution in Iran in 1979 had an impact on the Muslim world. It came, not primarily from the left, but from the religious establishment; not in the name of socialism, but in the name of Islam (Lapidus 2002: 485). Since the revolution, Shi'ite centers of Islamic learning in Iran, especially in the city of
Qum, have prospered. Over the years, the Islamic academies in Qum have trained the next generation of Shi'ite Muslims and religious leaders from across the Middle East and other parts of the globe. They spend years in Qum, learning Persian, Arabic, religious sciences, jurisprudence, theology and philosophy. Long stints of study in Qum allow them to forge cultural ties with Islamic Iran and learn much about the country. Time spent in Iran no longer impacts only the spirit of Islamic revolution to seminary students, but is also more likely to wind up exposing them to reformist and democratic thought (Nasr 2007: 217-218).

The Islamic Revolution subsequently impacted the Shi'ite communities in Thailand. The new republic has had a policy to export the Shi'ite revival to Shi'ite communities around the globe. As Shi'ite missionaries, Iranian sheikhs have propagated their religious ideas and practices in Shi' ite communities in Thailand. The Iranian government has also provided funding for religious activities in their communities and Iranian Shi'ite academic institutes have given scholarships to young people to study Islamic practices in Iran.

The Shi'ite revival stemming from the Islamic Republic of Iran is disseminated through their communities and has brought about changes in their rituals and culture. For example, the traditional taziyat that had been followed from the four hundred years' local conservative ritual, were changed, and some imambara buildings were also changed from the local to the Middle Eastern traditions.

During the transition period, Shi'ite Muslims in Thailand are informally separated into two groups. The original group who call themselves chao sen, 
meaning Imam Hussein's followers, have tried to conserve their traditional local culture and old ways. The other, who is called by the original group chi a mai, meaning the new Shi'ite, converted from other beliefs to revival Shi'ism. Their religious activities have been influenced by the new Iranization after the Islamic Revolution.

At present, these two groups of Shi'ite Muslims have different ideas. They are confronting new changes. The chao sen start to decrease in number while the chi a mai increase and try to expand their influence through the support of Iranian Islamic institutes. Thus Shi'ite Islam in Thailand is at this very moment in the process of vital changes once again after four hundred years of their establishment in the Buddhist Kingdom of Thailand.

\section{References}

Alam, Shah Manzur. 1959. Masulipatam: A Metropolitan Port in the Seventeenth Century. Islamic Culture 33.3: 169-87. Hyderabad, Deccan, India: Islamic Culture Board.

Andaya, Leonard Y. 1999. Ayutthaya and the Persian and India Muslim Connection. In From Japan to Arabia: Ayutthaya Maritime Relations with Asia, edited by Kennon Breazeale. Bangkok: Thammasat University Printing House.

Aphornsuvan, Thanet. 2003. History and Politics of the Muslims in Thailand. Revised edition. Bangkok: Thammasat University. (In Thai)

Arasaratnam, Sinnappah. 1984. The Coromandel-Southeast Asia Trade 1650-1740: Challenges and Responses of a Commercial System. Journal of Asian History 18.2:113-35. Wiesbaden, Germany: Harrassowitz Verlag.

Barbosa, Duarte. 1967. The Book of Duarte Barbosa. Volume 2. Millwood and New York: Kraus Reprint.

Chalayondecha, Prayoonsak. 1986. Muslims in Thailand (มุสลิมในประเทศ ไทย). Bangkok: Sultan Sulaiman Foundations. (In Thai)

Chardin, John. 1988. Travels in Persia 1673-1677. New York: Dover Publication.

Choisy, Abbé de. 1993. Journal of a Voyage to Siam 1685-1686. Kuala Lumpur: Oxford University Press.

Chularatana, Julispong. 2003. The Nobility in the Department of Foreign Affairs, Right Division: The Study of Role and Duty from Ayutthaya Period to Rattanakosin Period (ขุนนางกรมท่า ขวา: การศึกษาบทบาทและหน้าที่ในสมัยอยุธยา ถึงสมัยรัตนโกสินทร์ พ.ศ.2153-2435). Bangkok: Chulalongkorn Univerity Press. (In Thai)

---. 2004. Sheikh Ahmad: The Prelude of the Bunnag Family (เฉกอะหมัด: ปฐมบท สกุลบุนนาค). Art \& Culture Magazine (ศิลปวัฒนธรรม) 25.5: 94-105. (In Thai)

---. 2007. Muslim Communities during the Ayutthaya Period. MANUSYA 10.1: 94. Bangkok: Chulalongkorn University Press.

---. 2007. Chao Sen during the 
Rattanakosin Period (กรุ่นระบั่นบนชั้น ชะฎัต: เจ้าเซ็นครั้งแผ่นดินกรุงรัตนโกสินทร์). Journal of the Historical Society (วารสารสมาคมประวัติศาสตร์), Volume 29. Bangkok: The Royal Historical Society of Thailand. (In Thai)

Cole, J. R. I. 1988. Roots of North Indian Sh 'ism in Iran and Iraq. Berkeley: University of California Press.

Cortesoa, Armando (tr. and ed.). 1990. The Suma Oriental of Tomé Pires and the Book of Francisco Rodriques. Volume 1. New Delhi: Asian Educational Services.

Damrongrachanuphap, Prince. 1991. The Royal Chronicles of Ayutthaya, Royal Autograph Version (พระราชพงศาวดารกรุง ศรีอยุธยาฉบับพระราชหัตถเลขา). Bangkok: Chunum Sahakorn. (In Thai)

Datta, Kalikinkar; H. C. Raychaudhuri and R. C. Majumdar. 1987. An Advanced History of India. Madras: Macmillan India Press.

Dewongsa, Komcum. 1987. The Role of Ayutthaya's Market Places in Internal and External Trade (A.D.1630 A.D.1767). M.A. Thesis, Department of History, Faculty of Arts, Chulalongkorn University. (In Thai)

Floor, Willem. 2001. Safavid Government Institutions. Costa Mesa: Mazda Publishers.

Garnier, Derick. 2004. Ayutthaya Venice of the East. Bangkok: River Books.

Gervaise, Nicolas. 1989. The Natural and Political History of the Kingdom of
Siam. Translated by John Villiers. Bangkok: White Lotus.

Hall, D. G. E. 1994. A History of SouthEast Asia. 4th edition. Malaysia: Macmillan Press.

Kaempfer, Engelbert. 1987. A Description of the Kingdom of Siam 1690. Bangkok: White Orchid Press.

Kanjanakphan. 1974. The Geographic Studies of Wat Pho (ภูมิศาสตร์วัดโพธิ์). $2^{\text {nd }}$ edition. Bangkok: Burinth Publishers. (In Thai)

Keat Gin Ooi. 2004. Southeast Asia: A Historical Encyclopedia, from Angkor Wat to East Timor. Santa Barbara, CA, USA: ABC-CLIO.

Khurusapha. 1961a. A Collection of Poems Sung in Ayutthaya Royal Barge Processions (ประชุมกาพย์เห่เรือสมัยอยุธยา). Bangkok: Khurusapha. (In Thai)

---. 1961b. Royal Chronicles of Ayutthaya, Luang Prasert Version and Kromphra Paramanuchit Version and Northern Thai Chronicles, Phra Wichian Preecha (Noi) (พระราชพงศาวดารกรุงศรี อยุธยาฉบับหลวงประเสริฐและฉบับ กรมพระปรมานุชิตและพงศาวดารเหนือฉบับ พระวิเชียรปรีชา (น้อย)). Bangkok:

Khurusapha. (In Thai)

---. 1962. The Laws of the Three Seals Volume I (กฎหมายตราสามดวง เล่ม 1). Bangkok: Khurusapha. (In Thai)

---. 1968. Collected Historical Data Volume 25 (Part 41 - 43), French 
Merchants' Records (ประชุมพงศาวดาร เล่มที่ 25 , ประชุมพงศาวดารภาคที่ 41 (ต่อ) ถึง ภาคที่ $42-43$, จดหมายเหตุของคณะพ่อค้า ฝรั่งเศส). Bangkok: Khurusapha. (In Thai)

Krom Silpakorn. 1971. An Explanation of the Ayutthaya Map with Phraya Boran Rajchatanin's Opinions Concerning the Art and Historical Background of Ayutthaya and Phichit (อธิบายแผนที่พระนครศรีอยุธยากับคำวินิจฉัยของ พระยาโบราณราชธานินทร์เรื่องศิลปะและภูมิสถานกรุง ศรีอยุธยาและจังหวัดพิจิตร). Bangkok: Sammit Printing House. (In Thai)

---. 1972. Book of the Siamese Court Customs Volume 2 (ลัทธิธรรมเนียมต่าง ๆ เล่ม สอง). Bangkok: Klangwitthaya Press. (In Thai)

Kongchana, Plubplung. 1999. Historical Development of Cham Communities in Ayutthaya (พัฒนาการประวัติศาสตร์ชุมชน จามอยุธยา). Journal of History (วารสาร ประวัติศาสตร์), 67-80. Bangkok: Department of History, Faculty of Social Science, Srinakharinwirot University. (In Thai)

La Loubère, Simon de. 1969. The Kingdom of Siam. Kuala Lumpur: Oxford University Press.

Lach, Donald F. and Carol Flaumenhaft (eds.). 1965. Asia on the Eye of Europe's Expansion. Englewood Cliffs: Prentice-Hall.

Lailert, Busakorn. 1972. The Ban Phlu Luang Dynasty 1688-1767: A Study of the Thai Monarchy During the Closing Year of the Ayutthaya Period. Doctoral dissertation, University of London.

Lapidus, Ira M. 2002. A History of Islamic Societies. $2^{\text {nd }}$ edition. Cambridge: Cambridge University Press.

Limbert, John W. 1987. Iran at War with History. Boulder: Westview Press.

Marcinkowski, Muhammad Ismail. 2005. From Isfahan to Ayutthaya: Contacts between Iran and Siam in the $17^{\text {th }}$ Century. Singapore: Pustaka National.

Na Pombejra, Dhiravat. 1990. Crown Trade and Court Politics in Ayutthaya during the Reign of King Narai (165688). In The Southeast Asian Port and Polity: Rise and Demise, edited by J. Kathirithamby-Wells and John Villiers, pp. 127-42. Singapore: Singapore University Press.

Nasr, Vali. 2007. The Shia Revival. New York: W.W. Nortion.

Netton, Ian Richard. 1922. A Popular Dictionary of Islam. Worcester: Billing \& Son.

Pinto, Fernão Mendes. 1904. Subsidios para a sua Biografia. Translated by Christovao Aires. Lisbon: Academia das Ciencias.

Pongsripian, Winai (ed.). 1985. Thai Historical Data on Ayuttaya from Thai and Western documents (ข้อมูล ประวัติศาสตร์ไทยจากเอกสารไทยและ ต่างประเทศ). Nakhon Pathom: Department of History, Faculty of Arts, Silpakorn University. (In Thai)

Rabi, Muhammad. 1972. The Ship of Sulaiman. Translated by John O’ Kane. 
London: Routledge \& Keagan Paul.

Savoy, Roger. 1980. Iran Under the Safavids. Cambridge: Cambridge University press.

Scupin, Raymond. 1980. Islam in Thailand before the Bangkok Period. The Journal of Siam Society 68.1: 55-71.

Simon, Reeva S.; Philip Mattar and Richard W. Bulliet (eds.). 1996. Encyclopedia of the Modern Middle East, Volume 4, pp. 1652-1653. New York: Macmillan.

Smithies, Michael (tr.). 1997. Aspects of the Embassy to Siam 1685: The Chevalier de Chaumont and the Abbé de Choisy. Chiang Mai: Silkworm Books.

Suttakul, Nantha (tr.). 1970. The Dutch Papers in Ayutthaya Period (A.D.1608 - A.D.1620 and A.D.1624 - A.D.1642) เอกสารของฮอลันดาสมัยกรุงศรีอยุธยา พ.ศ. $2151-2163$ และพ.ศ. $2167-2185)$. Bangkok: Khurusapha. (In Thai)

Sykes, Percy. 1969. A History of Persia. Volume 2. $3^{\text {rd }}$ edition. London: Routledge and Keagan Paul.

Tabatabai, Husayn. 1989. Shi'a. Qum: Ansariyan.

Tachard, Guy. 1999. A Relation of the Voyage to Siam. Bangkok: White Lotus.

Teeuw, A. and David K. Wyatt. 1970. The Story of Pattani. Volume 2. The Hague: Nijhoff.

The Collected Laws of Islam (รวมกฎหมายว่า
ด้วยศาสนาอิสลาม). 1997. Bangkok:

Nidhivedh. (In Thai)

The Royal Institute. 1969. The Royal Institute Thai Encyclopedia (สารานุกรม ไทยฉบับราชบัณฑิตยสถาน). Volume 4. Bangkok: The Royal Institute of Thailand. (In Thai)

Thipakorawong, Chao Phraya. 1979. Book of Multifarious Duties (หนังสือแสดง กิจจานุกิจ). Bangkok: Khurusapha. (In Thai)

van Donzel, E. 1994. Islam Desk Reference. Leiden: E.J. Bill.

Whitaker, Donald P. 1973. Area Handbook for the Khmer Republic (Cambodia). Washington: U.S. Government Printing Office. 